\title{
The molecular phylogeny of the digenean family Opecoelidae Ozaki, 1925 and the value of morphological characters, with the erection of a new subfamily
}

\author{
Rodney A. Bray ${ }^{1}$, Thomas H. Cribb ${ }^{2}$, D. Timothy J. Littlewood ${ }^{1}$ and Andrea Waeschenbach ${ }^{1}$ \\ ${ }^{1}$ Department of Life Sciences, Natural History Museum, Cromwell Road, London, UK; \\ ${ }^{2}$ School of Biological Sciences, The University of Queensland, St Lucia, Queensland, Australia
}

\begin{abstract}
Large and small rDNA sequences of 41 species of the family Opecoelidae are utilised to produce phylogenetic inference trees, using brachycladioids and lepocreadioids as outgroups. Sequences were newly generated for 13 species. The resulting Bayesian trees show a monophyletic Opecoelidae. The earliest divergent group is the Stenakrinae, based on two species which are not of the type-genus. The next well-supported clade to diverge is constituted of three species of Helicometra Odhner, 1902. Based on this tree and the characters of the egg and uterus, a new subfamily, the Helicometrinae, is erected and defined to include the genera Helicometra, Helicometrina Linton, 1910 and Neohelicometra Siddiqi et Cable, 1960. The subfamily Opecoelinae is found to be monophyletic, but the Plagioporinae is paraphyletic. The single representative of the Opecoelininae (not of the type genus) is nested within a group of deep-sea 'plagioporines'. The two representatives of the Opistholebetidae are embedded within a group of shallow-water 'plagioporine' species. The Opistholebetidae is reduced to subfamily status pro tem as its morphological and biological characteristics are distinctive. This implies that as opecoelid systematics develops with more molecular evidence, several further subfamilies will be recognised. Many of the morphological characters were found to be homoplasious, but the characters defining the Helicometrinae and Opecoelinae, such as filamented eggs, reduced cirrus-sac and uterine seminal receptacle, are closely correlated with the inferred phylogeny.
\end{abstract}

Keywords: Digenea, Opecoelinae, Plagioporinae, Stenakrinae, Opecoelininae, rDNA sequence, Helicometrinae

This article contains supporting information (Figs. S1, S2) online at http://folia.paru.cas.cz/suppl/2016-63-013.pdf

The family Opecoelidae Ozaki, 1925 is the largest digenean family with over 90 genera and nearly 900 species, almost solely found in marine and freshwater teleost fishes. It is now considered to belong in the superfamily Opecoeloidea Ozaki, 1925 (see Littlewood et al. 2015) or the Brachycladioidea Odhner, 1905 (see Curran et al. 2006). Molecular studies have begun to elucidate the complexity of this large family, but as yet no clear pattern is emerging. There are several genera that are quite large, i.e. Plagioporus Stafford, 1904 (with 55 species), Podocotyle Dujardin, 1845 (55), Macvicaria Gibson et Bray, 1982 (51), Coitocaecum Nicoll, 1915 (50), Opecoelus Ozaki, 1925 (43), Opegaster Ozaki, 1928 (37), Pseudopecoelus Von Wicklen, 1946 (37) and Neolebouria Gibson, 1976 (25). The distinguishing characters for these genera are weak and rife with homoplasy, and as a result their demarcation and validity is constantly under discussion and disagreement.

For example, Cribb (2005a), in his key to the genera of the family, recognised the genus Opegaster as separate from Opecoelus on a "character of equivocal value", but that was "entrenched in the literature". On the other hand, Aken'Ova (2007) reviewed the controversy relating to these genera and synonymised them, forming many new combinations. Manter (1940) said "Actually some species seem close to the border line between the 2 genera". Crowcroft (1947) stated in relation to this problem that "The preferable course would seem to be the grouping of such similar species into one genus until such time as sufficiently clear sub-groups appear to warrant the setting up of several genera". Bray and Justine (2013) described a new species of Opegaster, discussed the generic distinction and stated "any worker who has struggled with opecoelid systematics will know, separation of taxa in this family is largely arbitrary and is a prime candidate for molecular solutions".

Cribb (2005a) reckoned that the "subfamily level classification within the Opecoelidae is complex and remains unsatisfactory". He recognised four subfamilies, the Opecoelinae Ozaki, 1925, Plagioporinae Manter, 1937, Stenakrinae Yamaguti, 1970 and Opecoelininae Gibson et Bray, 1984. These taxa are distinguished by the charac- 
ters of the male terminal genitalia and the female proximal genitalia. The Opecoelinae and Opecoelininae are characterised by a reduced or absent cirrus-sac, and are distinguished by the canalicular seminal receptacle being found only in the latter subfamily. The Plagioporinae and Stenakrinae share well-developed and muscular cirrus-sacs, and are differentiated by the presence of a canalicular seminal receptacle in the former. The family Opistholebetidae Fukui, 1929 has been considered close to the Opecoelidae and has been thought likely to be embedded within the Opecoelidae (Cribb 2005b).

This study is an attempt to use new and existing molecular data to assess the value of characters in the family and to present a preliminary phylogenetic estimate of the family.

\section{MATERIALS AND METHODS}

Fourteen partial large subunit nuclear ribosomal RNA gene $(l s r D N A=28 \mathrm{~S}$ rDNA) sequences (representing 13 species) and 13 almost complete small subunit nuclear ribosomal RNA gene ( $\operatorname{ss} D N A=18 \mathrm{~S}$ rDNA) sequences were newly generated (see Table 1) following the methodology outlined in Bray et al. (2012). These were aligned together with 29 published $\operatorname{sr} D N A$ sequences (representing 28 species) and seven published ssrDNA sequences (representing seven species) using MAFFT v.6.611b (Katoh et al. 2005) with 1000 cycles of iterative refinement and the genafpair algorithm. The alignment included four outgroup species representing the superfamilies Brachycladioidea (Zalophotrema hepaticum, Stephanostomum pristis [Deslongchamps, 1824]) and Lepocreadioidea Odhner, 1905 (Preptetos caballeroi Pritchard, 1960, Enenterum aureum Linton, 1910). Outgroup choice was informed by trees based on published $\operatorname{ls} \mathrm{SDNA}$ data from 556 species, representing 24 superfamilies and 97 families (see Littlewood et al. 2015). Alignments were examined by eye using Mesquite v.3.03 (Maddison and Maddison 2015). Ambiguously aligned positions were excluded manually. Alignments with indicated exclusion sets are available from the NHM Data Portal at http://dx.doi.org/10.5519/0009364. GenBank accession numbers for newly generated sequences are given in Table 1. Uncorrected p-distances were calculated using PAUP* v4.0b10 (Swofford 2003).

MrModeltest v.2.3 (Nylander 2004) was used to select appropriate models of nucleotide substitution using the Akaike information criterion. Phylogenetic trees for partitions $l s r D N A$, $s s r D N A$ and $l s r+s s r D N A$ were constructed using Bayesian inference (BI) with MrBayes v.3.2 (Huelsenbeck and Ronquist 2001, Ronquist and Huelsenbeck 2003). Likelihood settings were set to $\mathrm{nst}=6$, rates $=$ invgamma, ngammacat $=4$ (equivalent to the GTR $+\mathrm{I}+\Gamma$ model of nucleotide evolution). In the concatenated $l s r$ $+\operatorname{ss} D N A$ analyses model parameters were estimated separately for each partition. Four chains $($ temp $=0.2)$ were sampled every 1000 generations and run for 10000000 generations. 6000000 generations were discarded as 'burn-in', at which point the average standard deviation of split frequencies were $<0.01$. Nodes with $<0.95$ posterior probabilities (pp) were collapsed in the $l s r+$ ssrDNA tree (Fig. 1). Trees in nexus format are available from the NHM Data Portal at http://dx.doi.org/10.5519/0009364.

\section{RESULTS}

Of the aligned 1857 nucleotide positions in the $\operatorname{ss} D N A$ alignment, 58 were excluded. Of the aligned 1364 nucleotide positions in the $\operatorname{sr} D N A$ alignment, 137 were excluded. Thus the concatenated $l s r+s s r D N A$ dataset consisted of 3221 positions, of which 195 were excluded (see NHM Data Portal at http://dx.doi.org/10.5519/0009364 for alignments indicating exclusion sets). Because none of the strongly supported nodes in the individual gene partition trees (Figs. S1, S2) conflicted with the topology obtained from the concatenated $l s r+s s r D N A$ dataset (Fig. 1), description of the results will be based on the latter.

Under our current taxon sampling, the monophyly of the Opecoelidae was well supported (1.00 pp). The earliest diverging clade was composed of two species of Biospeedotrema Bray, Waeschenbach, Dyal, Littlewood et Morand, 2014 from a deep sea (hydrothermal vent) teleost; these are recognised here as probable representatives of the subfamily Stenakrinae Yamaguti, 1970. The clade forming the sister group to the remaining opecoelids was composed of the genus Helicometra Odhner, 1902, represented here by three species.

The remainder of the tree was split into two well-supported clades, one composed of members of the subfamily Opecoelinae, and a group of deep-sea and freshwater 'plagioporines' (Plagioporinae in Fig. 1) in which the opecoelinine Buticulotrema thermichthysi Bray, Waeschenbach, Dyal, Littlewood et Morand, 2014 nested. The other was composed of taxa mostly representing the subfamily Plagioporinae, consisting of three lineages whose relationships were unresolved. Pseudopycnadena tendu Bray et Justine, 2007 grouped separately from all other plagioporines as part of a polytomy including Clades A and B. Clade A consisted mostly of species of Macvicaria, which did not form a monophyletic group. However, sister-group relationships could be established for M. mormyri (Stossich, 1885) + M. crassigula (Linton, 1910) and M. obovata (Molin, 1859) + M. maamouriae Antar, Georgieva, Gargouri et Kostadinova, 2015. The recently described species M. bartolii Antar, Georgieva, Gargouri et Kostadinova, 2015, a replacement name for Mediterranean worms previously considered $M$. crassigula, took an unresolved position within Clade A. Macvicaria dubia (Stossich, 1905) also took an unresolved position in a subclade of Clade A, which amongst other Macvicaria representatives also included a clade composed of the opistholebetids, Maculifer sp. and Opistholebes amplicoelus Nicoll, 1915 and a well-supported but unresolved clade composed of Gaevskajatrema perezi (Mathias, 1926), Propycnadenoides philippinensis Fischthal et Kuntz, 1964 and Peracreadium idoneum (Nicoll, 1909).

Clade B was composed of a non-monophyletic Allopodocotyle Pritchard, 1966, where Allopodocotyle sp. A ex Scolopsis bilineatus (Bloch) formed the earliest diverging lineage and where Allopodocotyle epinepheli (Yamaguti, 1942) + Allopodocotyle sp. B ex Epinephelus coioides (Hamilton) were sister taxa grouping in an unresolved as- 
Table 1. List of species and details of provenance and GenBank Numbers. Taxa are listed according to Fig. 1.

\begin{tabular}{|c|c|c|c|c|c|c|}
\hline $\begin{array}{l}\text { Superfamily } \\
\text { Family }\end{array}$ & Parasite species & Host & Locality & $\begin{array}{l}\text { 28S Gen- } \\
\text { Bank No. }\end{array}$ & $\begin{array}{l}\text { 18S Gen- } \\
\text { Bank No. }\end{array}$ & References \\
\hline \multicolumn{7}{|l|}{ Brachycladioidea } \\
\hline Brachycladiidae & $\begin{array}{l}\text { Zalophotrema hepaticum Stunk- } \\
\text { ard et Alvey, } 1929\end{array}$ & Zalophus californianus & California, USA & AY222255 & AJ224884 & $\begin{array}{l}\text { Cribb et al. (2001), } \\
\text { Olson et al. (2003) }\end{array}$ \\
\hline Acanthocolpidae & $\begin{array}{l}\text { Stephanostomum pristis (De- } \\
\text { slongchamps, 1824) }\end{array}$ & Phycis phycis & Scandola, Corsica & DQ248222 & DQ248209 & Bray et al. (2005) \\
\hline \multicolumn{7}{|c|}{ Lepocreadioidea } \\
\hline Lepocreadiidae & $\begin{array}{l}\text { Preptetos caballeroi Pritchard, } \\
1960\end{array}$ & Naso vlamingii & Heron Island & AY222236 & AJ287563 & $\begin{array}{l}\text { Cribb et al. (2001), } \\
\text { Olson et al. (2003) }\end{array}$ \\
\hline Enenteridae & Enenterum aureum Linton, 1910 & Kyphosus vaigiensis & $\begin{array}{l}\text { Moorea, French } \\
\text { Polynesia }\end{array}$ & AY222232 & AY222124 & Olson et al. (2003) \\
\hline \multicolumn{7}{|l|}{ Opecoeloidea } \\
\hline Opecoelidae & $\begin{array}{l}\text { Biospeedotrema jolliveti Bray, } \\
\text { Waeschenbach, Dyal, Littlewood } \\
\text { et Morand, } 2014\end{array}$ & Ventichthys biospeedoi & $\begin{array}{l}\text { South East Pacific } \\
\text { Rise }\end{array}$ & KF733988 & KF733985 & Bray et al. (2014) \\
\hline Opecoelidae & $\begin{array}{l}\text { Biospeedotrema biospeedoi } \\
\text { Bray, Waeschenbach, Dyal, } \\
\text { Littlewood et Morand, } 2014\end{array}$ & Thermichthys hollisi & $\begin{array}{l}\text { South East Pacific } \\
\text { Rise }\end{array}$ & KF733986 & & Bray et al. (2014) \\
\hline Opecoelidae & Helicometra boseli Nagaty, 1956 & Sargocentron spiniferum & New Caledonia & KU320600 & KU320587 & Present study \\
\hline Opecoelidae & $\begin{array}{l}\text { Helicometra epinepheli Yama- } \\
\text { guti, } 1934\end{array}$ & Epinephelus fasciatus & New Caledonia & KU320597 & KU320584 & Present study \\
\hline Opecoelidae & $\begin{array}{l}\text { Helicometra manteri Andres, } \\
\text { Ray, Pulis, Curran et Overstreet, } \\
2014\end{array}$ & Prionotus alatus & Gulf of Mexico & KJ701238 & & Andres et al. (2014a) \\
\hline Opecoelidae & Helicometra manteri & Bellator egretta & Gulf of Mexico & KJ701239 & & Andres et al. (2014a) \\
\hline Opecoelidae & $\begin{array}{l}\text { Dimerosaccus oncorhynchi } \\
\text { (Eguchi, 1931) }\end{array}$ & Salvelinus curilus & $\begin{array}{l}\text { Kedrovaya River, } \\
\text { Russia }\end{array}$ & FR870262 & & Shedko et al. (2015) \\
\hline Opecoelidae & $\begin{array}{l}\text { Anomalotrema koiae Gibson et } \\
\text { Bray, } 1984\end{array}$ & Sebastes viviparus & Shetland Islands & KU320595 & KU320582 & Present study \\
\hline Opecoelidae & $\begin{array}{l}\text { Pseudopecoeloides tenuis Yama- } \\
\text { guti, } 1940\end{array}$ & Priacanthus hamrur & New Caledonia & KU320605 & KU320592 & Present study \\
\hline Opecoelidae & $\begin{array}{l}\text { Opecoeloides furcatus (Bremser } \\
\text { in Rudolphi, 1819) }\end{array}$ & Mullus surmuletus & Corsica & AF151937 & & Tkach et al. (2001) \\
\hline Opecoelidae & $\begin{array}{l}\text { Opecoeloides fimbriatus (Linton, } \\
1934 \text { ) }\end{array}$ & Micropogonias undulatus & $\begin{array}{l}\text { North Western Gulf } \\
\text { of Mexico }\end{array}$ & KJ001211 & & Andres et al. (2014b) \\
\hline Opecoelidae & $\begin{array}{l}\text { Bathycreadium brayi Pérez-del- } \\
\text { Olmo, Dallarés, Carrassón et } \\
\text { Kostadinova, 2014* }\end{array}$ & Trachyrincus scabrus & $\begin{array}{l}\text { Mediterranean } \\
\text { Spain }\end{array}$ & JN085948 & & Constenla et al. (2011) \\
\hline Opecoelidae & $\begin{array}{l}\text { Plagiocirrus loboides Curran, } \\
\text { Overstreet et Tkach, } 2007\end{array}$ & Fundulus nottii & Mississippi, USA & EF523477 & & Curran et al. (2007) \\
\hline Opecoelidae & $\begin{array}{l}\text { Podocotyloides brevis Andres et } \\
\text { Overstreet, } 2013\end{array}$ & Conger esculentus & $\begin{array}{l}\text { off western Puerto } \\
\text { Rico }\end{array}$ & KJ001212 & & Andres et al. (2014b) \\
\hline Opecoelidae & $\begin{array}{l}\text { Neolebouria lanceolata (Price, } \\
\text { 1934) }\end{array}$ & Polymixia lowei & $\begin{array}{l}\text { Eastern Gulf of } \\
\text { Mexico }\end{array}$ & KJ001210 & & Andres et al. (2014b) \\
\hline Opecoelidae & $\begin{array}{l}\text { Allopodocotyle margolisi Gib- } \\
\text { son, } 1995\end{array}$ & $\begin{array}{l}\text { Coryphaenoides } \\
\text { mediterraneus }\end{array}$ & Rockall Trough & KU320596 & KU320583 & Present study \\
\hline Opecoelidae & $\begin{array}{l}\text { Gaevskajatrema halosauropsi } \\
\text { Bray et Campbell, } 1996\end{array}$ & Halosauropsis macrochir & Goban Spur & AY222207 & AJ287514 & $\begin{array}{l}\text { Cribb et al. (2001), } \\
\text { Olson et al. (2003) }\end{array}$ \\
\hline Opecoelidae & $\begin{array}{l}\text { Buticulotrema thermichthysi } \\
\text { Bray, Waeschenbach, Dyal, } \\
\text { Littlewood et Morand, } 2014\end{array}$ & Thermichthys hollisi & $\begin{array}{l}\text { South East Pacific } \\
\text { Rise }\end{array}$ & KF733987 & KF733984 & Bray et al. (2014) \\
\hline Opecoelidae & $\begin{array}{l}\text { Pseudopycnadena tendu Bray et } \\
\text { Justine, } 2007\end{array}$ & Pseudobalistes fuscus & New Caledonia & FJ788506 & & Bray et al. (2009) \\
\hline Opecoelidae & $\begin{array}{l}\text { Macvicaria bartolii Antar, Geor- } \\
\text { gieva, Gargouri et Kostadinova, } \\
2015\end{array}$ & Diplodus annularis & $\begin{array}{l}\text { Bay of Bizerte, } \\
\text { Tunisia }\end{array}$ & KR149465 & & Antar et al. (2015) \\
\hline Opecoelidae & $\begin{array}{l}\text { Macvicaria mormyri (Stossich, } \\
1885 \text { ) }\end{array}$ & Lithognathus mormyrus & Scandola, Corsica & AF184256 & & Tkach et al. (2001) \\
\hline Opecoelidae & $\begin{array}{l}\text { Macvicaria crassigula (Linton, } \\
\text { 1910) }\end{array}$ & Calamus bajonado & Gulf of Mexico & KJ701237 & & Andres et al. (2014a) \\
\hline Opecoelidae & $\begin{array}{l}\text { Macvicaria dubia (Stossich, } \\
\text { 1905) }\end{array}$ & Oblada melanura & $\begin{array}{l}\text { Bay of Bizerte, } \\
\text { Tunisia }\end{array}$ & KR149470 & & Antar et al. (2015) \\
\hline Opistholebetidae & Maculifer $\mathrm{sp}$. & Diodon hystrix & Heron Island & AY222211 & AY222109 & Olson et al. (2003) \\
\hline Opistholebetidae & $\begin{array}{l}\text { Opistholebes amplicoelus Nicoll, } \\
1915\end{array}$ & Tetractenos hamiltoni & Stradbroke Island & AY222210 & AJ287550 & $\begin{array}{l}\text { Cribb et al. (2001), } \\
\text { Olson et al. (2003) }\end{array}$ \\
\hline Opecoelidae & $\begin{array}{l}\text { Macvicaria obovata (Molin, } \\
\text { 1859) }\end{array}$ & Gibbula adansonii & Ebro Delta, Spain & JQ694146 & & Born-Torrijos et al. (20 \\
\hline Opecoelidae & $\begin{array}{l}\text { Macvicaria maamouriae Antar, } \\
\text { Georgieva, Gargouri et Kostadi- } \\
\text { nova, } 2015\end{array}$ & Lithognathus mormyrus & $\begin{array}{l}\text { Bizerte Lagoon, } \\
\text { Tunisia }\end{array}$ & KR149468 & & Antar et al. (2015) \\
\hline
\end{tabular}


Table 1. Continued.

\begin{tabular}{|c|c|c|c|c|c|c|}
\hline $\begin{array}{l}\text { Superfamily } \\
\text { Family }\end{array}$ & Parasite species & Host & Locality & $\begin{array}{l}\text { 28S Gen- } \\
\text { Bank No. }\end{array}$ & $\begin{array}{l}\text { 18S Gen- } \\
\text { Bank No. }\end{array}$ & References \\
\hline \multicolumn{7}{|l|}{ Opecoeloidea } \\
\hline Opecoelidae & $\begin{array}{l}\text { Gaevskajatrema perezi } \\
\text { (Mathias, 1926) }\end{array}$ & ? Symphodus & Scandola, Corsica & AF184255 & & Tkach et al. (2001) \\
\hline Opecoelidae & $\begin{array}{l}\text { Propycnadenoides philippinensis } \\
\text { Fischthal et Kuntz, } 1964\end{array}$ & $\begin{array}{l}\text { symnocranius grandoc- } \\
\text { ulis }\end{array}$ & New Caledonia & KU320604 & KU320591 & Present study \\
\hline Opecoelidae & $\begin{array}{l}\text { Peracreadium idoneum (Nicoll, } \\
1909)\end{array}$ & Anarhichas lupus & North Sea & AY222209 & AJ287558 & $\begin{array}{l}\text { Cribb et al. (2001), } \\
\text { Olson et al. (2003) }\end{array}$ \\
\hline Opecoelidae & Allopodocotyle sp. A & Scolopsis bilineatus & New Caledonia & KU320599 & KU320586 & Present study \\
\hline Opecoelidae & $\begin{array}{l}\text { Allopodocotyle epinepheli } \\
\text { (Yamaguti, 1942) }\end{array}$ & Epinephelus cyanopodus & New Caledonia & KU320598 & KU320585 & Present study \\
\hline Opecoelidae & Allopodocotyle sp. B & Epinephelus coioides & Bali & KU320607 & KU320606 & Present study \\
\hline Opecoelidae & $\begin{array}{l}\text { Pacificreadium serrani (Nagaty } \\
\text { et Abdel-Aal, 1962) }\end{array}$ & Plectropomus leopardus & New Caledonia & KU320602 & KU320589 & Present study \\
\hline Opecoelidae & $\begin{array}{l}\text { Cainocreadium labracis (Dujar- } \\
\text { din, 1845) }\end{array}$ & Gibbula adansonii & Ebro Delta, Spain & JQ694144 & & Born-Torrijos et al. (2012) \\
\hline Opecoelidae & $\begin{array}{l}\text { Cainocreadium lintoni (Siddiqi } \\
\text { et Cable, 1960) }\end{array}$ & Epinephelus morio & $\begin{array}{l}\text { Off northern Virgin } \\
\text { Islands }\end{array}$ & KJ001208 & & Andres et al. (2014b) \\
\hline Opecoelidae & $\begin{array}{l}\text { Bentholebouria blatta (Bray et } \\
\text { Justine, 2009) }\end{array}$ & $\begin{array}{l}\text { Pristipomoides argyro- } \\
\text { grammicus }\end{array}$ & New Caledonia & KU320608 & & Present study \\
\hline Opecoelidae & Bentholebouria blatta & $\begin{array}{l}\text { Pristipomoides argyro- } \\
\text { grammicus }\end{array}$ & New Caledonia & KU320606 & KU320593 & Present study \\
\hline Opecoelidae & $\begin{array}{l}\text { Bentholebouria colubrosa An- } \\
\text { dres, Pulis et Overstreet, } 2014\end{array}$ & $\begin{array}{l}\text { Pristipomoides aqui- } \\
\text { lonaris }\end{array}$ & $\begin{array}{l}\text { Eastern Gulf of } \\
\text { Mexico }\end{array}$ & KJ001207 & & Andres et al. (2014b) \\
\hline Opecoelidae & $\begin{array}{l}\text { Macvicaria macassarensis } \\
\text { (Yamaguti, 1952) }\end{array}$ & Lethrinus miniatus & Heron Island & AY222208 & AJ287533 & $\begin{array}{l}\text { Cribb et al. (2001), } \\
\text { Olson et al. (2003) }\end{array}$ \\
\hline Opecoelidae & Hamacreadium 'mutabile' & Lutjanus fulviflamma & New Caledonia & KU320601 & KU320588 & Present study \\
\hline Opecoelidae & Hamacreadium sp. & Lethrinus miniatus & New Caledonia & KU320603 & KU320590 & Present study \\
\hline Opecoelidae & $\begin{array}{l}\text { Hamacreadium mutabile } \\
\text { Linton, } 1910\end{array}$ & Lutjanus griseus & $\begin{array}{l}\text { Eastern Gulf of } \\
\text { Mexico }\end{array}$ & KJ001209 & & Andres et al. (2014b) \\
\hline
\end{tabular}

* this species was identified as Bathycreadium elongatum by Constenla et al. (2011), but Pérez-del-Olmo et al. (2014) re-identified the material.

semblage together with (Pacificreadium serrani (Nagaty et Abdel-Aal, 1962) (Cainocreadium labracis (Dujardin, 1845), Cainocreadium lintoni (Siddiqi et Cable, 1960))), (Bentholebouria blatta (Bray et Justine, 2009), Bentholebouria colubrosa Andres, Pulis et Overstreet, 2014) and (Macvicaria macassarensis (Yamaguti, 1952) (Hamacreadium 'mutabile', Hamacreadium mutabile Linton, 1910, Hamacreadium sp.)).

\section{DISCUSSION}

\section{Monophyly of the Opecoelidae}

The monophyly of the family is convincingly demonstrated, with good support. The variety of types of terminal genitalia and proximal female genitalia discussed below all appear to be derived within the family.

\section{Subfamily Stenakrinae}

Gibson and Bray (1982) defined the subfamily as "forms possessing both a distinct cirrus-sac, containing an internal seminal vesicle, and a uterine seminal receptacle, but lacking both a naked seminal vesicle and a distinct canalicular seminal receptacle" and then later (Gibson and Bray 1984) they suggested that these characteristics "would appear to be the most primitive" in the family. The well-supported position of the putative stenakrines, Biospeedotrema spp., as the earliest diverging lineage adds some weight to this view. The long branch separating this subfamily from the remainder of the Opecoelidae may indicate that this taxon should be at the family rank, but unfortunately, no molecular data of species of Stenakron Stafford, 1904. are yet available. Whilst the position of Biospeedotrema is well supported in the analyses of $\operatorname{ssr} D N A$ (Fig. S1) and the concatenated dataset of $l s r+s s r D N A$ (Fig. 1), in the $l s r D N A$ tree the support is low $(0.67$ pp; Fig. S2). Other evidence, such as the tree produced by Shedko et al. (2015), lends support to the possibility that Biospeedotrema is not closely related to the Opecoelidae.

\section{Helicometra}

Although previous phylogenetic studies based on ITS ribosomal DNA (Jousson et al. 1999, Born-Torrijos et al. 2012, Barnett et al. 2014) provided conflicting and ambiguous results with regard to the position of Helicometra, our topology clearly places the genus Helicometra as sister group to the Opecoelinae and Plagioporinae. This reinforces the view that ITS sequences are clearly more useful for species distinction than higher level phylogeny (Nolan and Cribb 2005). As far as we are aware, no one has seen fit to recognise this genus (which has hitherto been considered a plagioporine along with its close relatives Helicometrina Linton, 1910 and Neohelicometra Siddiqi et Cable, 1960), as a separate, named taxon. In addition to its distinct phylogenetic position, this group is also characterised by striking morphological characters, i.e. the filamented eggs and the helical uterus. We, therefore, feel justified in erecting a new subfamily for Helicometra and morphologically similar worms. 


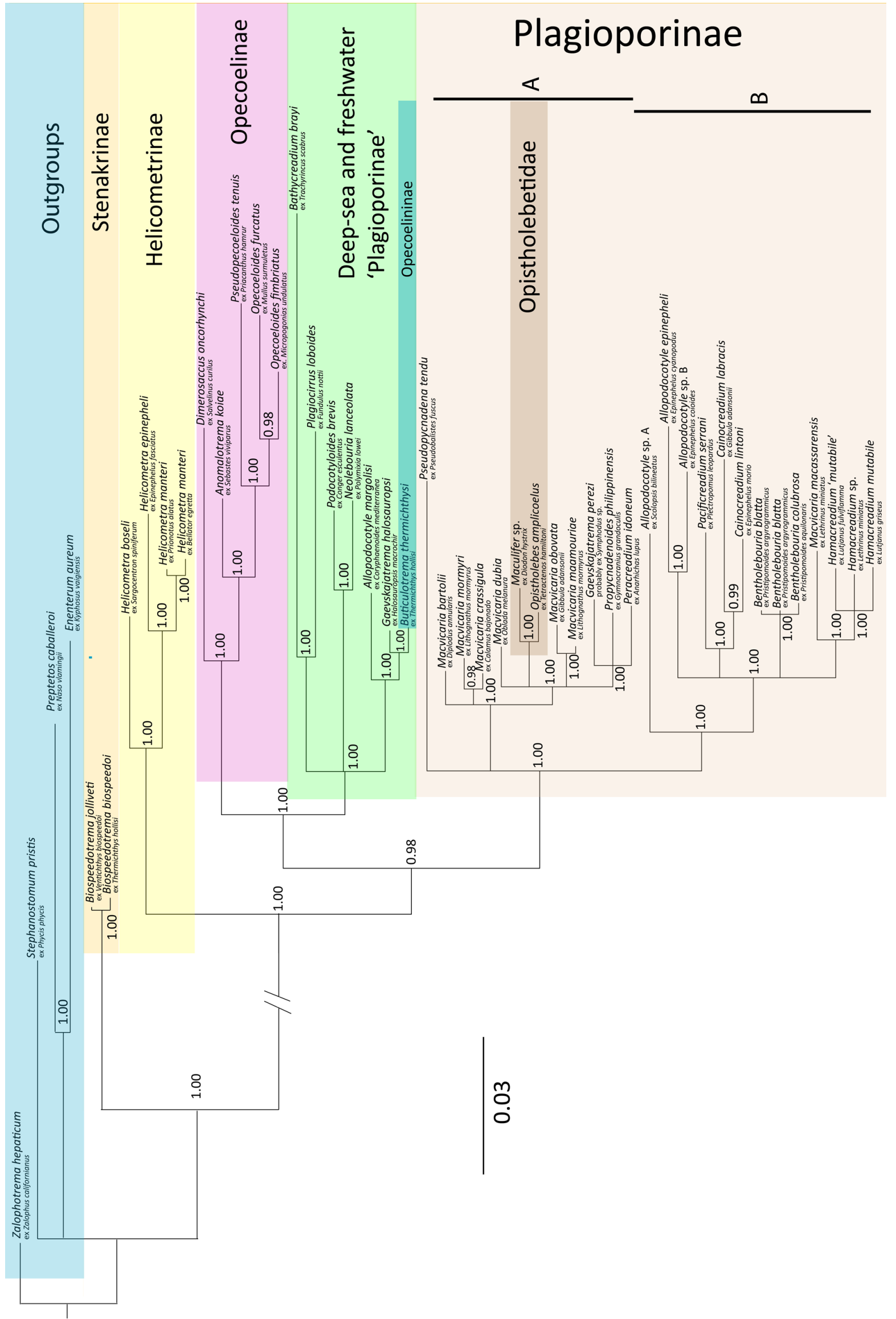

Fig. 1. Bayesian analysis of the concatenated $l s r+s s r D N A$ dataset constructed using MrBayes v3.2 under the GTR $+\mathrm{I}+\mathrm{G}$ model; 10000000 generations, 6000000 generations 'burn-in'. All nodes with $<0.95$ posterior probability have been collapsed. The branch length scale indicates number of substitutions per site. The length of the truncated branch is 0.11 . 


\section{Subfamily Helicometrinae subfam. n.}

ZooBank number for subfamily:

urn:1sid:zoobank.org:act:32FC2816-B7CE-42B5-B34A-9E54B9DBD152

Diagnosis. Opecoelidae. Body oval to elongate, with almost parallel margins, rounded posteriorly. Oral sucker unspecialised or distinctly funnel-shaped. Ventral sucker unspecialised, larger or smaller than oral sucker. Caeca blind, extending close to posterior end of body, or form ani. Testes two, or several (3-9), usually deeply lobed, occasionally almost entire, tandem to oblique; well separated from posterior end of body. Genital pore median or slightly submedian, bifurcal to pre-bifurcal. Ovary usually distinctly lobed, occasionally almost entire. Uterus distinctly helical, restricted to area between ovary and anterior testis and genital pore. Eggs with unipolar filaments. Vitelline follicles may enter forebody or be restricted to hindbody, extend posteriorly beyond testes to posterior end of body. Excretory vesicle extends to ovary. In many marine fish families; cosmopolitan.

Type genus: Helicometra Odhner, 1902 (syns. Stenopera Manter, 1933, Allostenopera Baeva, 1968, subgenus Metahelicometra Yamaguti, 1971). Other genera included in this subfamily due to their morphological similarity: Helicometrina Linton, 1910, Neohelicometra Siddiqi et Cable, 1960.

Helicometra boseli Nagaty, 1956 is here segregated as sister to $H$. epinepheli Yamaguti, $1934+H$. manteri Andres, Ray, Pulis, Curran et Overstreet, 2014. It is morphologically distinct from typical Helicometra spp. and Bray and Justine (2014), in discussing specimens from the same batch as that sequenced, considered that it may be appropriate to resurrect Stenopera Manter, 1933, to accommodate this and similar worms.

Interestingly, the two specimens of $H$. manteri which occurred in different hosts, Prionotus alatus Goode et Bean and Bellator egretta (Goode et Bean), in the Gulf of Mexico, differed by 7 nucleotides across the ribosomal RNA array (2433 bp) sequenced by Andres et al. (2014a) (see also branch lengths in Fig. 1 and Fig. S2). Although this amounts to only $0.3 \%$ difference, it may indicate that $H$. manteri may either be a complex of closely related species or an unusually genetically diverse population. Andres et al. (2014a) did note that H. manteri from Bellator spp. had 'a slightly more prominent lobed ovary than specimens recovered from $P$. alatus' (see also Figs. 1-3 in Andres et al. 2014a), but did not consider this sufficient evidence to separate them into discrete species. More elaborate morphological and molecular study of $H$. manteri across its host range ought to shed light on this issue.

Filamented eggs also occur in members of the plagioporine genus Diplobulbus Yamaguti, 1934, but it is not included here in the Helicometrinae as the filaments occur on both poles of the egg, the uterus reaches to the posterior extremity of the body and is not helical, and its ITS2 sequence places it distant from Helicometra (see Barnett et al. 2014).

\section{Remaining Opecoelidae}

The remaining Opecoelidae form a monophyletic clade which is subdivided into two major clades: (Opecoelinae + deep sea and freshwater 'Plagioporinae' + opecoelinine Buticulotrema thermichthysi) and (Plagioporinae with Opistholebetidae nested). Frustratingly, no morphological synapomorphies are apparent for these disparate groups.

\section{Opecoelinae}

This is a well-supported group, both in terms of molecular and morphological evidence. The subfamily Opecoelinae is characterised by possessing both a naked seminal vesicle and a uterine seminal receptacle, but lacking both a distinct cirrus-sac containing an internal seminal vesicle (a vestige of a cirrus-sac is present in some genera including the type-genus Opecoelus), and a canalicular seminal receptacle (Gibson and Bray 1982). The five species studied here all show these, apparently derived, characters. The subfamily is also characterised by a variety of posterior caecal arrangements. Dimerosaccus oncorhynchi (Eguchi, 1931), which forms the sister taxon to the remaining opecoelines, has typical digenean blind caecal endings (Shimazu 1980, Shedko et al. 2015). Anomalotrema koiae Gibson et Bray, 1984, which forms the sister taxon to Opecoeloides spp. and Pseudopecoeloides tenuis Yamaguti, 1940, has caeca which open separately ventrally to the excretory pore (Gibson and Bray 1984). The remaining three species, Pseudopecoeloides tenuis, Opecoeloides furcatus (Bremser in Rudolphi, 1819) and O. fimbriatus (Linton, 1934), share the same caecal endings, i.e. an uroproct, where the posterior caecal extremities open into the posterior part of the excretory vesicle (Yamaguti 1940, Sogandares-Bernal and Hutton 1959, Jousson and Bartoli 2000). Sogandares-Bernal and Hutton (1959) reckoned that " $(\mathrm{t})$ he presence of 2 ani or of a uroproct is dependent upon the contraction of the posterior end of the body in our specimens" and stated: "We believe that when the uroproct is formed very close to the posterior end of the body it does not serve as a good generic character." However, in most well-fixed specimens, and unless occluded by vitelline follicles, it is usually possible to distinguish these features. The Opecoelinae appears to be the most robust opecoelid subfamily of those presently recognised (see also Barnett et al. 2014) and there is no need for change.

\section{Deep-sea and freshwater 'Plagioporinae' + Buticulotrema (Opecoelininae)}

Seven species constitute the sister clade to the Opecoelinae, five of which are deep-sea plagioporine-like worms, one is a freshwater species and one, confusingly, is a hydrothermal vent 'opecoelinine'. This clade is strongly supported (1.00 pp), but the relationships of the three well-supported internal lineages are not resolved.

Although well supported (1.00 pp), the clade including Bathycreadium brayi Pérez-del-Olmo, Dallarés, Carrassón et Kostadinova, 2014 and Plagiocirrus loboides Curran, Overstreet et Tkach, 2007 is puzzling. Bathycredium brayi was collected from 600-647 m depth in the Mediterranean 
Sea (Pérez-del-Olmo et al. 2014), in contrast to the freshwater form $P$. loboides from the Pascagoula River in Mississippi (Curran et al. 2007). It should be noted, however, that the branch-length to both species is long. There are no apparent synapomorphies for these two worms. It is likely that the type-genus of the subfamily Plagioporinae, i.e. Plagioporus, now considered a freshwater genus, will be in this clade. The clade consisting of Podocotyloides brevis Andres et Overstreet, 2013 from $200 \mathrm{~m}$ depth (Andres and Overstreet 2013) and Neolebouria lanceolata (Price, 1934) from 329-430 m (Andres et al. 2014b), both in the Gulf of Mexico/Puerto Rico region, is biologically reasonable, although, apart from being typical 'plagioporines', they share no obvious morphological synapomorphy (Price 1934).

The third clade (1.00 pp) includes three deep-sea forms: Allopodocotyle margolisi Gibson, 1995 from 1745-2220 m depth from the Rockall Trough off NW Scotland (Gibson 1995), Gaevskajatrema halosauropsi Bray et Campbell, 1996 at 2570 m depth from the Goban Spur, NE Atlantic Ocean (new depth data) and Buticulotrema thermichthysi from $2598 \mathrm{~m}$ depth from a hydrothermal vent site on the South East Pacific Rise (Bray et al. 2014). The placement of $B$. thermichthysi in this position is perplexing. Bray et al. (2014) stated that the material of the hydrothermal vent worms they described had endured suboptimal fixation, but the study of wholemounts and sections show fairly unambiguously that the cirrus-sac is missing in this species. The seminal receptacle is described as saccular, presumably canalicular, which is the arrangement found in the closest relatives in the tree.

\section{The main Plagioporinae clade}

\section{Separate position of Pseudopycnadena}

Pseudopycnadena tendu, a robust, oval species from a coral reef fish off New Caledonia (Bray and Justine 2007), grouped separately from the remaining members of this clade. It is rather atypical morphologically, with its broadly oval cirrus-sac containing a massive field of large gland-cells, and the annular ridge on the ventral surface which, it is presumed, functions as an accessory attachment organ. Nevertheless, in general, the terminal genitalia and proximal female system conform to the normal plagioporine pattern.

\section{Clade A}

\section{Non-monophyly of Macvicaria}

The species of Macvicaria in clade A parasitise sparid fishes (Linton 1910, Bartoli et al. 1993, Antar et al. 2015) in the western Mediterranean Sea and the Gulf of Mexico, but they do not constitute a monophyletic group. Macvicaria obovata and M. maamouriae appear as sister taxa and, although they are similar species and are both found in sparids in the Mediterranean Sea, they have no obvious synapomorphies (Bartoli et al. 1989, Antar et al. 2015). The $M$. obovata sequence is derived from parthenitae in a snail, but the identification has been verified by ITS comparison by Born-Torrijos et al. (2012).

Macvicaria crassigula and M. mormyri also appear as sister taxa. The former species was originally described off the Dry Tortugas, Florida (Linton 1910) and the sequence is from a worm from the Gulf of Mexico and from a congener of the type-host, whereas $M$. mormyri is a Mediterranean worm (Bartoli et al. 1993). Although reported many times in both the Mediterranean and the Gulf of Mexico region, $M$. crassigula has never been described in detail. It is likely that it does not occur in the Mediterranean Sea, or at least some of the Mediterranean records are of M. bartolii (see Antar et al. 2015). No obvious synapomorphies unite M. mormyri and M. crassigula. Macvicaria macassarensis, from lethrinids and nested in clade B, is clearly only distantly related to the sparid parasites.

\section{More comments on Clade A}

The monophyletic clade composed of Peracreadium idoneum, Propycnadenoides philippinensis and Gaevskajatrema perezi is not characterised by any obvious synapomorphies or distributional or host similarities. All are fairly typical plagioporines. Peracreadium idoneum is a north Atlantic species found in wolffishes (Anarhichas spp., Anarhichadidae) (Nicoll 1909, Bray 1987), P. philippinensis is found in large-eye bream (Gymnocranius spp., Lethrinidae) in the western Pacific Ocean (Bray and Cribb 1989) and Gaevskajatrema perezi is a poorly known species from labrids supposedly found in the north-eastern Atlantic, Mediterranean and Black Seas (Gibson and Bray 1982). Provenance data on the specimen of $G$. perezi are vague, particularly in relation to host.

The nesting of the two opistholebetids within a clade of plagioporines poses a taxonomic challenge. Both are from the coast of Queensland and bear similar morphological and biological characteristics. Opistholebes amplicoelus is known only from tetraodontids from this region. Cribb (2005b) considered that there were four distinguishing features for the family Opistholebetidae: the posterior position of the ventral sucker, the presence of a post-oral (muscular) ring, the presence of pigment granules and the parasitism in diodontid and tetraodontid fishes. None of these features occur in the related plagioporines. The position of the opistholebetids identified here, nested deep among typical opecoelids, makes the retention of family-level recognition for the group untenable. However, the biological and morphological distinctness of the group suggest to us that it should continue to be recognised in a supra-generic taxon, in this case the subfamily Opistholebetinae Fukui, 1929, stat. emend.

\section{Clade B}

The worms in Clade B are all typical plagioporines and in many cases are difficult to distinguish. An isolated undescribed Allopodocotyle sp. A from a nemipterid fish is the sister to the remaining internal clades, which form a 4-way polytomy. Two species of Allopodocotyle from Epinephelus spp. in the Indo-West Pacific Region form 
a well-supported clade. These are morphologically practically indistinguishable, but clearly distinct genetically. The position of Allopodocotyle margolisi in the other major opecoelid clade, along with other deep-sea fish parasites, indicates that some convergence appears to have occurred. Allopodocotyle margolisi is the only deep-sea member of the nominal genus and is genuinely deep-sea, having been found at depth between 1700-3500 m off the west coast of Scotland and at the Mid-Atlantic Ridge (Gibson 1995, Kellermanns et al. 2009).

The two closely related species of Bentholebouria Andres, Pulis et Overstreet, 2014 formed a well-supported clade. Bentholebouria blatta was represented by two identical sequences from worms collected from the same host and locality. Both species are found in relatively deep-water lutjanids of the genus Pristipomoides Bleeker (see Bray and Justine 2009, Andres et al. 2014b). Intriguingly and surprisingly, the $l s r D N A$ sequence of $B$. colubrosa from the Gulf of Mexico differed by only two nucleotide positions, i.e. $0.016 \%$, from that of B. blatta from New Caledonia.

The final clade in B includes four morphologically similar species, three of them belonging to the genus Hamacreadium Linton, 1910. The sister to Hamacreadium spp. is Macvicaria macassarensis, which is from the same host, Lethrinus miniatus (Forster), as Hamacreadium sp. and is placed in Macvicaria based on the entire, rather than lobed ovary (Bray and Cribb 1989, Cribb 2005a). It also differs from Hamacreadium spp. in the excretory vesicle, which reaches to the posterior edge of the ventral sucker (Yamaguti 1952, Bray and Cribb 1989), but not into the forebody as is characteristic of Hamacreadium. Hamacreadium mutabile is a widely reported parasite mainly of lutjanid fishes, and our worms from New Caledonia have been identified as this species (Justine et al. 2012). Morphologically it is similar to the Gulf of Mexico form, but molecular evidence from $l s r D N A$ suggests that $H$. 'mutabile' and $H$. $m u$ tabile are as distinct from each other, as Hamacreadium sp. and $H$. 'mutabile' are from each other, i.e. $0.2 \%$ difference in pairwise sequence comparisons. The Gulf of Mexico $H$. mutabile material is from the type host in the eastern Gulf of Mexico, close to the type locality of Dry Tortugas, Florida (Linton 1910, Andres et al. 2014a). The relationships amongst the species of Hamacreadium are not resolved.

\section{Type species}

The following species are the type species of their respective genera: Biospeedotrema jolliveti Bray, Waeschenbach, Dyal, Littlewood et Morand, 2014, Dimerosaccus oncorhynchi, Pseudopecoeloides tenuis, Opecoeloides furcatus, Propycnadenoides philippinensis, Gaevskajatrema perezi, Opistholebes amplicoelus, Bentholebouria colubrosa, Pacificreadium serrani, Cainocreadium labracis and Hamacreadium mutabile. If these are correctly identified, then they can be taken as genuine representatives of the genera in question.

\section{Generic polyphyly}

Of the nine genera represented by more than one species, six appear monophyletic: Biospeedotrema (2 spe- cies), Helicometra (3), Opecoeloides Odhner, 1928 (2), Bentholebouria (2), Cainocreadium Nicoll, 1909 (2), Hamacreadium (3). On the other hand, three are polyphyletic: Allopodocotyle (4), Gaevskajatrema Gibson et Bray, 1982 (2), Macvicaria (7). The four species of Allopodocotyle appear in three places in the tree and the seven Macvicaria species appear in five places. There are about 13 nominal species in Allopodocotyle and 51 in Macvicaria. Macvicaria and Allopodocotyle in particular are considered particularly unsatisfactory genera, with dubious, general, plesiomorphic defining characteristics, such as details of the vitelline distribution and the shape of the ovary.

\section{Morphological characters}

The morphological differentiating characters were discussed in detail by Cribb (2005a). Here we comment on these characters in the light of our molecular tree.

Body shape: This is a difficult character to define as it is a continuum. Four opecoelines are elongate and as they are monophyletic it might be considered a useful character. Some of the other worms are also on the border-line of this character state, e.g. Bathycreadium brayi and Podocotyloides brevis, but it does appear to be the case that really elongate worms are most common in the Opecoelinae.

Tegument: Occasional spines, usually absent. None of the species studied have tegumental spines.

Oral sucker: All species studied have an oval subterminal oral sucker.

Ventral sucker: All species but one have an unelaborated ventral sucker. The ventral sucker of Propycnadenoides philippinensis has muscular lamellar lips.

Ventral sucker peduncle: This character is found in a monophyletic group of opecoelines (Pseudopecoeloides Yamaguti, 1940 and Opecoeloides). One plagioporine species, Podocotyloides brevis, also has this character.

Ventral sucker position: One species, Opistholebes amplicoelus, actually has a posteriorly situated ventral sucker. It was this character that led, in part, to the previous recognition of the Opistholebetidae.

'Accessory sucker': This appears as an autapomorphy of the genus Opecoeloides.

Gut length: Several species scattered in the tree have relatively short caeca, i.e. not reaching significantly into the post-testicular region. The only combination of taxa for which this might be a synapomorphy is the two Biospeedotrema spp.

Gut termination: Blind caeca are by far the most common arrangement. Two ani occur in Anomalotrema koiae; a uroproct occurs in Pseudopecoeloides and Opecoeloides. As discussed above it appears that these states may be a progression. These appear to be a useful characters and, in our tree, occur only in the opecoelines. Bathycreadium brayi has a cyclocoel.

Excretory vesicle: A long excretory vesicle extending into the forebody is a characteristic of Hamacreadium species, but it also occurs in Pacificreadium serrani, where it becomes distinctively diverticulate. In general, excretory vesicle length appears to be an informative character, although difficult to define in some cases. A very short excre- 
tory vesicle is found in Biospeedotrema and Opistholebes Nicoll, 1915 and is probably a useful generic character, but with considerable homoplasy.

Excretory pore: In two species, Pseudopycnadena tendu and Opistholebes amplicoelus, the excretory pore is displaced onto the dorsal surface. These species are not particularly closely related. It seems likely that this character is of some value, as has been found in the Lepocreadiidae (see Bray 2005), but our sample of worms with this character is too small to be informative.

Testis number: All species studied have two testes.

Testis arrangement: Tandem and symmetrical testes arrangements are scattered amongst the species in the tree. In two cases symmetrical testes may be a synapomorphy for a clade, i.e. the two Biospeedotrema spp. and (Gaevskajatrema halosauropsi + Buticulotrema thermichthysi). The condition may be of value, but tends to homoplasy.

Testis shape: Species with entire or lobate testes are found throughout the tree. Lobed testes are found in all three Helicometra species sampled, although this state is not invariant in the genus (Sekerak and Arai 1974).

Cirrus-sac presence: Significant reduction in the cirrus-sac is a good character defining the Opecoelinae. The reduction may be in the size where, as in Dimerosaccus Shimazu, 1980, the cirrus-sac now encloses only a small distal portion of the male terminal genitalia. On the other hand, it may be, as in Anomalotrema Zhukov, 1957, reduced to a thin membrane. Ultimately, the cirrus-sac may be completely absent, as in the monophyletic group (Pseudopecoeloides + Opecoeloides). Parallel complete reduction in the cirrus-sac appears to have occurred in Buticulotrema thermichthysi.

Genital pore: This may be submedian or median. This seemingly slight difference, in fact, appears to be important even if prone to homoplasy. Several monophyletic groups have a median genital pore, e.g. Biospeedotrema spp., Helicometra spp., 'Opistholebetidae' and Pacificreadium Durio et Manter, $1968+$ Cainocreadium. An isolated case is Peracreadium idoneum.

Ovary: Presence or absence of lobation of the ovary may be of some value, although to be utilised with caution. It is exhibited by the monophyletic groups Hamacreadium spp., Opecoeloides spp., Bentholebouria spp., Pacificreadium + Cainocreadium and Hamacreadium spp. Elsewhere in the tree this character appears scattered in isolated species.

Vitellarium anterior extent: In all the opecoeline species and (Allopodocotyle epinepheli + Allopodocotyle sp. B ex Epinephelus coioides) the vitellarium does not reach into the forebody. Elsewhere the character occurs sporadically. This character has often, but not invariably, been used as a generic character. It is not always reliable, even as a specific character (as in Opecoelus variabilis Cribb, 1985, see Cribb 1985).

Vitellarium posterior extent: The vitellarium does not extend posteriorly beyond the testes in the Stenakrinae and Gaevskajatrema. This appears to be a good character, but with some homoplasy.
Egg size: Members of the genera Choerodonicola Cribb, 2005 and Diplobulbus have relatively tiny eggs $(<32 \mu \mathrm{m}$ long). No species with eggs of this size were sampled.

Egg filament: A unipolar filament is a good character, a synapomorphy of the Helicometrinae. Bipolar filaments, which occurs only in Diplobulbus, do not occur amongst the species in our sample.

There are thus remarkably few useful morphological characters available to distinguish a large number of taxa. There clearly is substantial homoplasy, and uncertainty about the nature of the basal condition, in the characters that we do have. It therefore comes as no surprise that molecular phylogenetic analysis shows our current classification to be seriously deficient.

\section{Concluding remarks}

It seems obvious that the present subfamily structure of the Opecoelidae is quite unsatisfactory. Given the incomplete molecular data set that is presently available for analysis, it is clear that we should step warily in proposing change. Two issues arise. How important is it to recognise subfamilial taxa and what is presently plausible? For a taxon comprising so many genera and species, we consider it desirable that subfamilies are recognised if and as they become convincing and informative. Some clades recognised here are morphologically and (in some cases) biologically distinct and their recognition at the subfamily level seems useful. In this category we consider that the Opecoelinae and Stenakrinae, as presently recognised, show signs of remaining useful and robust taxa.

We argue, in addition, that the genus Helicometra and its relatives are now unarguably distinct from all other opecoelid clades and that it is appropriate to recognise a subfamily for them. Of the remaining taxa, we conclude that the Plagioporinae can now be considered no more than a work-in-progress which will ultimately require the recognition of multiple subfamilies. In our view, these certainly cannot yet be distinguished reliably, especially in the absence of sequence information for the type-genus Plagioporus. However, we do observe that the close relationship of two opistholebetid genera to taxa in one minor clade of 'plagioporines' renders it no longer defendable to recognise the Opistholebetidae as a distinct family. As a concept, this taxon is appealing given the combination of its relatively distinct morphology and narrow host range. We propose that it should now be recognised at the subfamily level.

Such recognition implies that ultimately we may need to recognise many further subfamilies of opecoelids; on the basis of the topology discussed here it could easily be as many as ten. However, for a taxon as rich and complex as the Opecoelidae this should come as no real surprise. We thus can look forward to the challenge that lies ahead of the combined recognition of the clades of opecoelids and the understanding of their biological and evolutionary basis, confused as it is by conservative morphology and rampant homoplasy.

The study has also shown that the dissatisfaction with the generic boundaries voiced by many earlier authors (see 
Cribb 2005a) is justified. One third of the genera represented by more than one species are polyphyletic. Not only are they polyphyletic, but their constituents are well separated in the tree.

This study has contributed significantly to our understanding of the value of morphological characters in opecoelid systematics. The characters separating the Opecoelinae, namely the reduced or absent cirrus-sac and the uterine seminal receptacle, seem in this case to be highly informative, but these characters, separately, are found elsewhere in the tree. The reduced cirrus-sac of Buticulotrema thermichthysi, the only putative representative of the subfamily Opecoelininae (see Gibson and Bray 1984, Bray et al. 2014), suggests that this character is homoplasious and that this subfamily is embedded within a plagiopo- rine-like clade. The uterine seminal receptacle found in the Stenakrinae, represented here by the two species of Biospeedotrema, similarly appears to be convergent. The lack of samples from the type genera of these two subfamilies is to be regretted and emphasises the need for much further work. Nevertheless, this exercise has given us many useful insights into the phylogeny and systematics of this difficult group.

Acknowledgements. The generation of new sequences was funded by a Life Sciences Molecular Taxonomic Support grant from the Natural History Museum, London. We thank the staff of the NHM sequencing facility for sample processing. We are grateful to the collectors of the material used, in particular Jean-Lou Justine for allowing us to use material from New Caledonia.

\section{REFERENCES}

Aken'Ova T.O. 2007: The taxonomic status of Opegaster Ozaki, 1928 and the description of four new species of Opecoelus Ozaki, 1925 (Digenea: Opecoelidae) from marine teleosts in Australian waters. Syst. Parasitol. 67: 25-42.

Andres M.J., Overstreet R.M. 2013: A new species of Podocotyloides (Digenea: Opecoelidae) from the grey conger eel, Conger esculentus, in the Caribbean Sea. J. Parasitol. 99: 619-623.

Andres M.J., Pulis E.E., Overstreet R.M. 2014b: New genus of opecoelid trematode from Pristipomoides aquilonaris (Perciformes: Lutjanidae) and its phylogenetic affinity within the family Opecoelidae. Folia Parasitol. 61: 223-230.

Andres M.J., Ray C.L., Pulis E.E., Curran S.S., Overstreet R.M. 2014a: Molecular characterization of two opecoelid trematodes from fishes in the Gulf of Mexico, with a description of a new species of Helicometra. Acta Parasitol. 59: 405-412.

Antar R., Georgieva S., Gargouri L., Kostadinova A. 2015 Molecular evidence for the existence of species complexes within Macvicaria Gibson \& Bray, 1982 (Digenea: Opecoelidae) in the western Mediterranean, with descriptions of two new species. Syst. Parasitol. 91: 211-229.

Barnett L.J., Miller T.L., Cribb T.H. 2014: A review of the currently recognised opecoelid cercariae, including the identification and emergence ecology of Cercaria capricornia XII (Digenea: Opecoelidae) from Nassarius olivaceus (Gastropoda: Nassariidae) in Central Queensland, Australia. Parasitol. Int. 63 : 670-682.

Bartoli P., Bray R.A., Gibson D.I. 1989: The Opecoelidae (Digenea) of sparid fishes of the western Mediterranean. III. Macvicaria Gibson \& Bray, 1982. Syst. Parasitol. 13: 167-192.

Bartoli P., Gibson D.I., Bray R.A. 1993: The Opecoelidae (Digenea) of sparid fishes of the western Mediterranean VI. A redescription of Macvicaria mormyri (Stossich, 1885) n. comb. and a key to the opecoelids from western Mediterranean sparids. Syst. Parasitol. 26: 59-67.

Born-Torrijos A., Kostadinova A., Raga J.A., Holzer A.S 2012: Molecular and morphological identification of larval opecoelids (Digenea: Opecoelidae) parasitising prosobranch snails in a Western Mediterranean lagoon. Parasitol. Int. 61: 450-460.

BRAY R.A. 1987: A study of the helminth parasites of Anarhichas lupus (Perciformes: Anarhichadidae) in the North Atlantic. J. Fish Biol. 31: 237-264

Bray R.A. 2005: Family Lepocreadiidae Odhner, 1905. In: A. Jones, R.A. Bray and D.I. Gibson (Eds.), Keys to the Trematoda. Volume 2. CABI Publishing and the Natural History Museum, Wallingford, pp. 545-602.

Bray R.A., CribB T.H. 1989: Digeneans of the family Opecoelidae Ozaki, 1925 from the southern Great Barrier Reef, including a new genus and three new species. J. Nat. His. 23: 429-473.
Bray R.A., Foster G.N., Waeschenbach A., Littlewood D.T.J. 2012: The discovery of progenetic Allocreadium neotenicum Peters, 1957 (Digenea: Allocreadiidae) in water beetles (Coleoptera: Dytiscidae) in Great Britain. Zootaxa 3577: 58-70.

Bray R.A., Justine J.-L. 2007: Pseudopycnadena tendu sp. nov. (Digenea, Opecoelidae) in the yellow-spotted triggerfish Pseudobalistes fuscus (Perciformes, Balistidae) and additional opecoelids parasitizing fishes from the waters off New Caledonia. Acta Parasitol. 52: 13-17.

Bray R.A., Justine J.-L. 2009.: Neolebouria blatta n. sp. (Digenea: Opecoelidae) from Pristipomoides argyrogrammicus (Valenciennes) and Etelis carbunculus Cuvier (Perciformes: Lutjanidae) off New Caledonia. Syst. Parasitol. 74: 161-167.

Bray R.A., Justine J.-L. 2013: A digenean parasite in a mudskipper: Opegaster ouemoensis sp. n. (Digenea: Opecoelidae) in Periophthalmus argentilineatus Valenciennes (Perciformes: Gobiidae) in the mangroves of New Caledonia. Folia Parasitol. 60: 7-16.

Bray R.A., Justine J.-L. 2014: Helicometra boseli Nagaty, 1956 (Digenea: Opecoelidae) in Sargocentron spiniferum (Forsskål) (Beryciformes: Holocentridae) from New Caledonian waters with a review of the Helicometra spp. in holocentrids. Syst. Parasitol. 89: 167-173.

Bray R.A., Waeschenbach A., Cribb T.H., Weedall G.D., Dyal P., LitTLEwood D.T.J. 2009: The phylogeny of the Lepocreadioidea (Platyhelminthes: Digenea) inferred from nuclear and mitochondrial genes: implications for their systematics and evolution. Acta Parasitol. 54: 310-329.

Bray R.A., Waeschenbach A., Dyal P., Littlewood D.T.J., Morand S. 2014: New digeneans (Opecoelidae) from hydrothermal vent fishes in the south eastern Pacific Ocean, including one new genus and five new species. Zootaxa 3768: 73-87.

Bray R.A., Webster B.L., Bartoli P., Littlewood D.T.J. 2005: Relationships within the Acanthocolpidae Lühe, 1906 and their place among the Digenea. Acta Parasitol. 50: 281-291.

Constenla M., CARrassón M., Moyà C.M., Fernàndez-Chacón A., Padrós F., Repullés-Albelda A., MonteRO F.E. 2011: Parasitisation by Bathycreadium elongatum (Digenea, Opecoelidae) in pyloric caeca of Trachyrincus scabrus (Teleostei, Macrouridae). Dis. Aquat. Org. 96: 239-247.

CRIBB T.H. 1985: The life cycle and biology of Opecoelus variabilis, sp. nov. (Digenea: Opecoelidae). Aust. J. Zool. 33: 715-728.

Cribb T.H. 2005a: Family Opecoelidae Ozaki, 1925. In: A. Jones, R.A. Bray and D.I. Gibson (Eds.), Keys to the Trematoda. Volume 2. CABI Publishing and the Natural History Museum, Wallingford, pp. 443-531.

CribB T.H. 2005b: Family Opistholebetidae Fukui, 1929. In: A. Jones, R.A. Bray and D.I. Gibson (Eds.), Keys to the Trematoda. Volume 2. CABI Publishing and the Natural History Museum, Wallingford, pp. 533-539. 
Cribb T.H., Bray R.A., Littlewood D.T.J., Pichelin S., Herniou E.A. 2001: The Digenea. In: D.T.J. Littlewood and R.A. Bray (Eds.), Interrelationships of the Platyhelminthes, Taylor \& Francis, London, pp. 168-185.

Crowcroft P.W. 1947: Some digenetic trematodes from fishes of shallow Tasmanian waters. Pap. Proc. R. Soc. Tasm. 81: 5-25.

Curran S.S., Overstreet R.M., Tkach V.V. 2007: Phylogenetic affinities of Plagiocirrus van Cleave and Mueller, 1932 with the description of a new species from the Pascagoula river, Mississippi. J. Parasitol. 93: 1452-1458.

Curran S.S., Tkach V.V., Overstreet R.M. 2006: A review of Polylekithum Arnold, 1934 and its familial affinities using morphological and molecular data, with description of Polylekithum catahoulensis sp. nov. Acta Parasitol. 51: 238-248.

Gibson D.I. 1995: Allopodocotyle margolisi n. sp. (Digenea: Opecoelidae) from the deep-sea fish Coryphaenoides (Chalinura) mediterraneus in the northeastern Atlantic. Can. J. Fish. Aquat. Sci. 52: 90-94.

Gibson D.I., Bray R.A. 1982: A study and reorganization of Plagioporus Stafford, 1904 (Digenea: Opecoelidae) and related genera, with special reference to forms from European Atlantic waters. J. Nat. Hist. 16: 529-559.

Gibson D.I., Bray R.A. 1984: On Anomalotrema Zhukov, 1957, Pellamyzon Montgomery, 1957, and Opecoelina Manter, 1934 (Digenea: Opecoelidae), with a description of Anomalotrema koiae sp. nov. from North Atlantic waters. J. Nat. Hist. 18: 949964.

Huelsenbeck J.P., Ronquist F. 2001: MRBAYES: Bayesian inference of phylogenetic trees. Bioinformatics 17: 754-755.

Jousson O., Bartoli P. 2000: The life cycle of Opecoeloides columbellae (Pagenstecher, 1863) n. comb. (Digenea, Opecoelidae): evidence from molecules and morphology. Int. J. Parasitol. 30: 747-760.

Jousson O., Bartoli P., Pawlowski J. 1999: Molecular identification of developmental stages in Opecoelidae (Digenea). Int. J. Parasitol. 29: 1853-1858.

Justine J.L., Beveridge I., Boxshall G.A., Bray R.A., Miller T.L., Moravec F., Trilles J.P., Whittington I.D. 2012: An annotated list of fish parasites (Isopoda, Copepoda, Monogenea, Digenea, Cestoda, Nematoda) collected from snappers and bream (Lutjanidae, Nemipteridae, Caesionidae) in New Caledonia confirms high parasite biodiversity on coral reef fish Aquat Biosyst. 8: 1-22.

Katoh K., Kuma K.-I., Toh H., Miyata T. 2005: MAFFT version 5: improvement in accuracy of multiple sequence alignment. Nucl. Acids Res.3: 511-518.

Kellermanns E., Klimpel S., Palm H.W. 2009: Parasite fauna of the Mediterranean grenadier Coryphaenoides mediterraneus (Giglioli, 1893) from the Mid-Atlantic Ridge (MAR). Acta Parasitol. 54: 158-164.

Linton E. 1910: Helminth fauna of the Dry Tortugas. II. Trematodes. Papers Tortugas Lab. Carnegie. Inst. Wash. 4: 11-98.

Littlewood D.T.J., Bray R.A., Waeschenbach A. 2015: Phylogenetic patterns of diversity in cestodes and trematodes. In: S. Morand, B. Krasnov and D.T.J. Littlewood (Eds.), Parasite Diversity and Diversification: Evolutionary Ecology meets
Phylogenetics. Cambridge University Press, Cambridge, pp. 304-319.

MadDison W.P., MadDison D.R. 2015: Mesquite: a modular system for evolutionary analysis, http: //mesquiteproject.org, 01/2016.

Manter H.W. 1940: Digenetic trematodes of fishes from the Galapagos Islands and the neighboring Pacific. Allan Hancock Pacif. Expeds 2: 325-497.

NicOLL W. 1909: Studies on the structure and classification of the digenetic trematodes. Q. J. Microsc. Sci. 53: 391-487.

Nolan M.J., CribB T.H. 2005: The use and implications of ribosomal DNA sequencing for the discrimination of digenean species. Adv. Parasitol. 60: 101-163.

Nylander J.A.A. 2004: MrModeltest v2. Program distributed by the author, https: //www.abc.se/ nylander/, 01/2016.

Olson P.D., Cribb T.H., TKach V.V., Bray R.A., Littlewood D.T.J. 2003: Phylogeny and classification of the Digenea (Platyhelminthes: Trematoda). Int. J. Parasitol. 33: 733-755.

Pérez-del-Olmo A., Dallarés S., Carrassón M., KostadiNOva A. 2014: A new species of Bathycreadium Kabata, 1961 (Digenea: Opecoelidae) from Phycis blennoides (Brünnich) (Gadiformes: Phycidae) in the western Mediterranean. Syst. Parasitol. 88: 233-244.

Price E.W. 1934: New digenetic trematodes from marine fishes. Smithsonian Misc. Coll. 91: 1-8.

RonQuist F., Huelsenbeck J.P. 2003: MRBAYES 3: Bayesian phylogenetic inference under mixed models. Bioinformatics 19: 1572-1574.

Sekerak A.D., Arai H.P. 1974: A revision of Helicometra Odhner, 1902 and related genera (Trematoda: Opecoelidae), including a description of Neohelicometra sebastis n. sp. Can. J. Zool. 52: 707-738.

Shedko M.B., Sokolov S.G., Atopkin D.M. 2015: The first record of Dimerosaccus oncorhynchi (Trematoda: Opecoelidae) in fishes from rivers of Primorsky Territory, Russia, with a discussion on its taxonomic position using morphological and molecular data. Parazitologiya 49: 171-189.

Shimazu T. 1980: Dimerosaccus gen. nov. (Digenea: Opecoelidae), with a redescription of its type species, Dimerosaccus oncorhynchi (Eguchi, 1931) comb. nov. Jpn. J. Parasitol. 29: 163-168.

Sogandares-Bernal F., Hutton R.F. 1959: Studies on helminth parasites from the coast of Florida. III. Digenetic trematodes of marine fishes from Tampa and Boca Ciega Bays. J. Parasitol. 45: 337-346.

Swofford D.L. 2003: PAUP* Phylogenetic Analysis Using Parsimony (* and other methods), Version 4. Sunderland, MA: Sinauer Associate.

Tkach V.V., Pawlowski J., Mariaux J., Swiderski Z. 2001: Molecular phylogeny of the suborder Plagiorchiata and its position in the system of Digenea. In: D.T.J. Littlewood and R.A. Bray (Eds.), Interrelationships of the Platyhelminthes. Taylor \& Francis, London, pp. 186-193.

Yamaguti S. 1940: Studies on the helminth fauna of Japan, Part 31. Trematodes of fishes, VII. Jpn. J. Zool. 9: 35-108.

Yamaguti S. 1952: Parasitic worms mainly from Celebes. Part 1. New digenetic trematodes of fishes. Acta Med. Okayama 8: 146-198. family Opecoelidae Ozaki, 1925 and the value of morphological characters, with the erection of a new subfamily. Folia Parasitol. 63: 013 . 